\title{
Religious Philosophy of Bhagat Singh
}

\section{Dr. Dinesh Kumar}

Assistant Professor, Amity School of Liberal Arts, Amity University Haryana, India

\begin{abstract}
The article focuses on how Bhagat Singh as a great freedom fighter in the entire history of India is a well-recognised national hero by every common citizen and intellectual. It also explores how he was a revolutionary not only on the political front but also on social and religious fronts. His ideas are deeply rooted in a deep sense of social and political understanding in many ways. Bhagat Singh as a social-political thinker always tried to be rational and construct strong base against any irrational and illogical elements present in the society. He has proclaimed an atheist but his views on the religious front are remarkable. He never advocated people to follow any religion blindly and stay on illusion. He condemned everything that seemed damaging and destructive for the Indian society. He was more concerned about the progress of people irrespective of any identity and created a universal platform for everyone at the national level. He also presented his views over the Gods and their different roles for humanity in his writings and thoughts. While talking about the divine figure and religion his prime concern had been to benefit people without any disparity and difference. Bhagat Singh throughout his life fought against the sufferings that affected human lives. At the same time, he questioned the authority of those who were responsible to carry the religious elements by criticising the caste system and religious practices of India. He questioned the highest Varna of society by arguing that if he commits any sin who would be responsible and who is authorised to punish him. In other words, he until the end of time stood against any nexus that harms humanity and human lives in any form. His prime objective in life had been to inject revolutionary ideas among the people and impart a heart that opened its door for everyone without any reservations. In the end, he concluded himself as an atheist on the basis his observations of the religious elements.
\end{abstract}

Keywords—Bhagat Singh, religion, God, Revolutionary, Movement.

\section{INTRODUCTION}

"For selfish motives, I am not going to pray. Readers and friends, is this vanity? If it is, I stand for it."

\section{Why I am an Atheist?}

Bhagat Singh in the history of India is considered as a symbol of youth icon and revolutionary who developed a very different kind of the cult of freedom fighters during the national movements. His name itself is a synonym of many endless ideas that made him well recognised revolutionary in the history of the freedom movement. The revolutionary cult developed by Bhagat Singh had a clear vision by way of nationalism, rationalism, and future of society. He received the nationalist spirit in legacy from his for-fathers. His courage, intellect, and sacrifice are beyond the reach of any other revolutionary and freedom fighters of his time. He was a well-known political thinker of his time due to his rational query and thoughts. Bhagat Singh in his life was well versed in literature, tradition, and
Indian culture. His revolutionary ideas and spirit for independence have not only changed the political scenario of the struggle for freedom but also created a stage for socialist thoughts. His farsighted vision can be realised in his ideas of revolution, socialism, violence, religion, and way of life. His ideas always challenged the imperialists who tried to portray him as terrorist and anarchist.

While dealing with the religious ideas of Bhagat Singh it is proposed that one must know every viewpoint of religion before engaging in religious beliefs and practices. In the writings of Bhagat Singh, it is advocated for everyone to have faith in ones' own abilities to attain the goal in life instead, depending upon the storytelling, religious symbols, and religious practices. He argues that religious elements cannot be as a guide to stride through the complexities of life. ${ }^{1} \mathrm{He}$ has clearly expressed his views on religion in his; work "Why I am an Atheist." His revolutionary ideas and

${ }^{1}$ https://www.thebetterindia.com/wp 
thinking was mainly the by-product of several new factors. All his idea originated from the previous revolutionary movements during the First World War. Every idea and revolution was directly dependent on its milieu. It was the period of Non-cooperation movement in the 1920s.

Bhagat Singh has founded many organisations and remained an active member of these organisations with full dedication. He was the founder of Punjab Naujawan Sabha and actively associated with the Gadar Party, which existed during the World War-I. ${ }^{2}$ He was a revolutionary activist throughout his life. His ideological search was to find out human emancipation from the obnoxious effects of religious and social practices. At the beginning of school days, he was deeply impressed by the revolutionary heroes such as Sardar Ajit Singh, Lala Hardayal. Under the influence of Lala Hardayal, Bhagat Singh is founded the Hindustan Republican Association in 1928. Thus, his bold steps can be realised with the foundations of such institutions and his active engagement. Bhagat Singh with his fellow revolutionaries, Sukhdev and Rajguru became not only a martyr but known as a great ideologue for others across the country.

Bhagat Singh when he was in jail expressed the throbbing of people and wrote various articles and books on diverse issues of revolutionaries and society. His revolutionary ideas were not only getting freedom from British oppressive government but also get rid of from the orthodox concepts of religion. In his ideological discourse, he realised the attachment of people with their religious traditions, therefore he wanted to eliminate the irrationality of the religious practices and create awareness among the people to be more rational and logical.

\section{RELIGIOUS VIEWS OF BHAGAT SINGH}

Bhagat Singh brought into light the many issues of religion based on his experiments and experiences. He had been well aware of the dangers of religious practices and its use by the few individuals for personal benefits and exploitation of the innocents. He opposed any kind of discrimination based on caste and religion. He denied the existence of any such religion that creates deference between the people of the same society. He advocated the continuation of the co-existence of all the religions irrespective of their majority and minority to establish harmony and unity in the society. He realised the religious extremism in every aspect of life which resulted in the

\footnotetext{
${ }^{2}$ J.N., Sanyal, Sardar Bhagat Singh, Blumoon Books, New Delhi, 2010, p.26
}

stratification and decimation in the society. Caste system and untouchably are the worst by-products of religion in Indian society. Caste has multiplied the discriminatory attitudes of people in which God is especially under the control of the priestly class. Those who were at the last steps of the caste hierarchy exploited the most.

The philosophy of Bhagat Singh was influenced by Karl Marx, Trotsky and Lenin and consequently, he spent most of the time analysing the history of revolutionaries and different movements. He started writing on against the social and religious odds in the false name of virodhi. ${ }^{3}$ The philosophy of religion was based on his meticulous readings and a deep sense of understanding. He talked of the Tolstoy division into three parts; essentials of religion, philosophy of religion and rituals of religion. Going through the religious discourse he argues that if religion means blind faith by mixing rituals with philosophy them it must be thrown away without any hesitation for the betterment of society. On the other hand, if religion is combined with essentials with philosophy then it may be meaningful for humanity. ${ }^{4} \mathrm{He}$ strongly believed that that the ritualistic part of any religion is the main cause behind the division among the people. Religious lines have always been dividing factor of our people and used as a tool by the foreign rulers. He accepts it very honestly that there are many killing of people in the name of religion on different junctures. ${ }^{5}$ Riots are obvious examples of the killing of people in the name of religions in pre and postindependence of India.

Bhagat Singh always believed that difference and discriminations based on the religious lines must be removed from the social construction, if not, people will join other religions where they feel they have more respects and rights.

The new concept of social-globalization tries to give different dimensions to women's identity. He also had a strong belief that no one should be forced to change his/her religion rather we must work towards the removal of ageold inequalities the religions. Either way, he has always respected the religious beliefs and faith of people. We all

3 Anam, Iftikhar and Muhammad Iqbal, Chawla, Recontextualizing Bhagat Singh's Freedom Struggle for Independence of India, Journal of the Research Society of Pakistan, Volume No. 55, Issue No. 1(January - June 2018), p.20.

${ }^{4}$ S. Ifan Habib, Bhagat Singh A Shared Revolutionary Legacy Between India and Pakistan, Marxist, XXXIII, 4, October-December 2017, p. 2.

${ }^{5}$ Ibid. 
are equal and none is different due to either birth or occupation. He and his fellow revolutionaries in one meeting of Naujawan Bharat Sabha in 1926, at Lohore openly raised their voice against any kind of appeasement of all religions and discarded slogans like Allah o Akbar, Sat Sri Akal and Bande Mataram to prove their secularism. Furthermore, he supported the clear-cut separation of religion from politics. ${ }^{6}$

Being a true political thinker, he raised many issues of society and changed the entire scenario of freedom movements through his deep understanding and analysis. In the same direction, he wrote one of the most profound articles by him called, 'Why I am an Atheist' when he was in jail. Bhagat Singh in this article before unfolding anything about religion has tried to identify the religiosity of his procedures. His clear view was that the lack of scientific knowledge had been the source of development of unreasonable religious ideas in the world. Nevertheless, he believed that religion and mysticism had pacified the many quests of the people in many ways. Hence, mysticism and religion are complementary to each other. ${ }^{7}$ In his view, religion should not be the source of inspiration for revolutionaries.

\section{BHAGAT SINGH ON GOD}

About God, Bhagat Singh writes;

He (God) was to serve as a father, mother, sister and brother, friend and helper. . . so that when the man is in great distress having been betrayed and deserted by all friends, he may find consolation in the idea that an ever true friend was still there to help him, to support him and that He was Almighty and could do anything. Really that was useful to a society in the primitive age. The idea of God is helpful to man in distress. ${ }^{8}$ In Bhagat Singh's opinion, religion is a tool in the hands of exploiters and few people in society create fear in the name of almighty or God. The revolutionaries of the Hindustan Socialist Republican Association (HSRA) realized that not all moral ideals and religions are going to fulfil their requirement, instead, the basic needs are God for them.

\footnotetext{
6 Ibid. p. 3.

${ }^{7}$ Ibid. p. 4

${ }^{8}$ Bhagat Singh, Why I am an Atheist, Essay by the Indian Revolutionary and freedom fighter, Bhagat Singh, written while imprisoned in Lahore in 1930. Published after his death on 27 September 1931 in Lala Lajpat Rai's English weekly The People.
}

Bhagat Singh aptly quoted Horace Greeley in his prison diary saying 'Morality and religion are but words to him who fishes in gutters for the means of sustaining life and crouches behind barrels in the street for shelter from the cutting blasts of a winter night. ${ }^{9}$ Another freedom fighter, Baba Randhir Singh, who was in the jail same jail with Bhagat Singh tried to convince him about the Gods existence, but failed. Baba lost his temper and said tauntingly: "You are giddy with fame and have developed and ago which is standing like a black curtain between you and the God." 10 The entire article 'Why I am an Atheist' is the reply of Bhagat Singh against the Baba Randhir Singh's idea of God. In this writing, he argues that God is present because of my ignorance. He said; I am after all human being, and nothing more. He argues again that only two things are possible; either a man wishes to possess the Godly qualities or he moves a step further and declares himself to be a God. ${ }^{11}$

Bhagat Singh never associated him with God for any reason. I have been completely atheistic in my belief. But whenever he is asked about the existence of his humble reply remained same that you may believe in him when you feel it, but at the same time in his only book 'Bandi Jivan'(incarnated life) Singh, sings and praises to the glory of God. ${ }^{12} \mathrm{He}$ said that I could not understand the logic behind religious support and the existence of God. The origin of atheism in me is not the result of any specific condition instead; it is my will not to believe in any God. He once said that my revolutionary ideas might be anti-god but certainly not anti-human. ${ }^{13}$ Bhagat Singh in his writing "The martyrs of 1914-15" had advocated for the separation of religion from politics. If religion and concept of god are kept away from politics, we all together can initiate a revolution in a better manner, although we all belonged to different religions. ${ }^{14} \mathrm{He}$ even questioned the authority of God by asking if he is omnipresent, why, people commit sins or offence. ${ }^{15}$

\footnotetext{
${ }^{9}$ The Jail Notebook of Bhagat Singh

10 भगत सिंह, मैं नास्तिक क्यों हूँ, प्रकाशन, बाबा रंधीर सिंह, 1931. P. 10

${ }^{11}$ Bhagat Singh, Why I am an Atheist, 1931, p. 1.

12 Sachindranath Sanyal, Bandi Jivan, Atmaram and Sons, Delhi, 1938, p. 344.

${ }^{13}$ The Manifesto of $H$. S. R . A., December 1929.

${ }^{14}$ Praveen, Dawar, A true revolutionary: What Lay behind the Political philosophy of Bhagat Singh, The Asian Age, March 20, 2019.

${ }^{15}$ Irfan, Habib, Inquilab: Bhagat Singh on Religion and Revolution, Sage Publication, New Delhi, 2018, p. 54.
} 
IV.

CONCLUSION

While dealing with the religious philosophy of Bhagat Singh it can be concluded that during the revolutionary days of his life, he has challenged the various fundamentals of religious tradition and its role in society. He learned the basics of revolution and social ethics in the initial stage of his life from the family and his schooling. In his view, religion is not the solution to our problems and it cannot gain the aim of our lives. In many sense, one has to think against the religions to overcome or break the illogical chain of it. He always advocated keeping religion separate from the politics and other philosophies of lives. The practice of different kind of religious ideas will lead to the difference among people that will culminate infraction in the thoughts of the people.

\section{REFERENCES}

[1] Deol, G.S., Shaheed-e-Azam Sardar Bhagat Sing--The Man and His Ideology, Gurbax Deep, Ludhiana, 1978.

[2] Habib, Irfan, Inquilab: Bhagat Singh on Religion and Revolution, Sage Publication, New Delhi, 2018

[3] Nayyar, Kuldeep, The Martyr Bhagat Singh: Experiments in Revolution, New Delhi, Har-Anand Publications, 2000.

[4] Noorani, A. J., The Trial of Bhagat Singh; Politics of Justice, Oxford University Press, Oxford, 1996.

[5] Praveen, Dawar, A true revolutionary: What Lay behind the Political philosophy of Bhagat Singh, The Asian Age, March 20, 2019.

[6] Rao, Niraja, Bhagat Singh and the Revolutionary Movement, 1997.

[7] Readers Delight, Biography of Shaheed Bhagat Singh; Revolutionary Leader and freedom Fighter, Ramesh Publishing House, New Delhi, 2017.

[8] Sachindranath Sanyal, Bandi Jivan, Atmaram and Sons, Delhi, 1938.

[9] Sanyal, J. N., Amar Shahe ed Sardar Bhagat Singh (Hindi), NBT, Mirzapur, 1970.

[10] Sanyal, J. N., Sardar Bhagat Singh, Blumoon Books, New Delhi, 2010.

[11] Sunil K. Mishra, STRENGTHS OF WOMEN AND HUMAN RIGHTS. http://doi.org/10.5281/zenodo.3785343 International Journal of Research and Analytical Reviews (2020).

[12] The Jail Notebook of Bhagat Singh

[13] The Manifesto of H.S. R. A., December 1929.

[14] भगत सिंह, मैं नास्तिक क्यों हूँ, प्रकाशन, बाबा रंधीर सिंह, 1931. P. 10

[15] Habib, S. Ifan, Bhagat Singh A Shared Revolutionary Legacy between India and Pakistan, Marxist, XXXIII, 4, October-December 2017, p. 2.

[16] Iftikhar, Anam, and Iqbal, Chawala, Muhammad, Recontextualizing Bhagat Singh's Freedom Struggle for
Independence of India, Journal of the Research Society of Pakistan, Volume No. 55, Issue No. 1(January - June 2018), p.20.

[17] Singh, Bhagat, Why I am an Atheist, Essay by the Indian Revolutionary and freedom fighter, Bhagat Singh, written while imprisoned in Lahore in 1930. Published after his death on 27 September 1931 in Lala Lajpat Rai's English weekly The People.

[18] https://www.thebetterindia.com/wp 